\title{
IL-4 fails to regulate in vitro beryllium-induced cytokines in berylliosis
}

\author{
L.A. Maier*,\#, R.T. Sawyer*, , S.S. Tinkle ${ }^{+}$, L.A. Kittle*, E.A. Barker*, R. Balkissoon*,\#, C. Rose*,\#, \\ L.S. Newman*,\#
}

IL-4 fails to regulate in vitro beryllium-induced cytokines in berylliosis. L.A. Maier, R.T. Sawyer, S.S. Tinkle, L.A. Kittle, E.A. Barker, R. Balkissoon, C. Rose, L.S. Newman. (C) ERS Journals Ltd 2001.

ABSTRACT: Bronchoalveolar lavage (BAL) cells from patients with chronic beryllium disease (CBD) have been used to evaluate the beryllium-specific immune response and potential immunotherapeutics. Beryllium induces interferon- $\gamma($ IFN- $\gamma)$, interleukin-2 (IL-2), tumour necrosis factor- $\alpha$ (TNF- $\alpha$ ), interleukin-6 (IL-6) and interleukin-10 (IL-10) from BAL cells. An antibody to IL-2 and recombinant human (rHu) IL-10 is able to partially suppress the beryllium-stimulated immune response. To obtain BAL cells, bronchoscopy is required, providing risk to the patient and a limited number of cells to study the immune response. As a result, the objectives of the study were to determine 1) whether CBD peripheral blood mononuclear cells (PBMNs) stimulated with beryllium would produce a similar cytokine pattern as BAL cells, and 2) whether this response could be modulated by interleukin-4 (IL-4), an immunomodulatory cytokine.

CBD and normal individuals' $\mathrm{PBMN}$ and BAL cells were stimulated with and without beryllium sulfate. To modulate this antigen-stimulated response, we added rHu IL-4 to the unstimulated and beryllium-stimulated cells. IFN- $\gamma$, IL-2, TNF- $\alpha$, IL-6 and IL-10 cytokine concentrations were determined from cell supernatants by enzyme-linked immunosorbent assays (ELISA), while IL-4 messenger ribonucleic acid (mRNA) was assessed using polymerase chain reaction (PCR).

Beryllium did not stimulate any of these cytokines from normal PBMNs. Increasing levels of IL-6 and TNF- $\alpha$ were produced constituitively by CBD PBMNs over time. Compared to the unstimulated CBD PBMNs, beryllium stimulated significant IFN- $\gamma$, TNF- $\alpha$, IL-2, IL-6 and IL-10 production. This response was similar to that stimulated from CBD BAL cells, although of a much lower magnitude. Low levels of IL-4 mRNA were found in CBD and control PBMNs, which were not increased with beryllium stimulation. The beryllium-stimulated cytokine levels were not decreased by the addition of IL-4. IL-4 was unable to downregulate any of these beryllium-stimulated cytokines from CBD BAL cells or increase IL-4 mRNA from either CBD PBMN or BAL cells, and thus is an unlikely immunomodulatory agent in CBD.

From the data, it was concluded that chronic beryllium disease peripheral blood mononuclear cells provide a model to study the beryllium-stimulated immune response. Interleukin-4's inability to downregulate any of the beryllium-stimulated cytokines makes it an unlikely therapeutic candidate in chronic beryllium disease.

Eur Respir J 2001; 17: 403-415.
*Division of Environmental and Occupational Health Sciences, National Jewish Medical and Research Center, Denver, CO, ${ }^{\text {\#}}$ Division of Pulmonary Science and Critical Care Medicine, Dept of Medicine and Dept of Preventive Medicine and Biometrics, University of Colorado Health Sciences Center, Denver, CO, Division of Pulmonary Science and Critical Care Medicine, Dept of Medicine, University of Colorado Health Sciences Center, Denver, $\mathrm{CO}$, and ${ }^{+}$National Institute of Occupational Safety and Health, Morgantown, WV, USA

Correspondence: L. Maier, National Jewish Medical and Research Center, 1400 Jackson Street, Denver, CO 80206, USA

Fax: 13033981452

\section{Keywords: Berylliosis}

beryllium

cytokines

granuloma

IL-4

Received: February 22000

Accepted after revision September 13 2000

This work was supported in part by Grant HL0785-23, Grant 5 K08 HL03887, Grant R29 ES-06538, and Grant M01 RR00051 from the National Institutes of Health, U.S. Public Health Service.
Chronic beryllium disease (CBD) is a granulomatous lung disease that results from exposure to beryllium in the workplace [1]. The current understanding of the disease leads to the belief that individuals with CBD first develop a sensitization to beryllium, demonstrated by a positive peripheral blood beryllium lymphocyte proliferation test (BeLPT) $[1,2]$. Some of these individuals eventually develop CBD, which is defined by the presence of a positive blood or bronchoalveolar lavage (BAL) BeLPT, plus granulomatous inflammation on lung biopsy $[1,2]$.

In $\mathrm{CBD}$ and other granulomatous lung diseases such as sarcoidosis, mixed bronchoalveolar lavage cells have been used as a model to evaluate the cellular immune response [3-5]. It appears that the pathogenesis of CBD begins with alterations in alveolar/capillary permeability [6] and lung recruitment of berylliumspecific $\mathrm{CD}^{+}{ }^{+}$T cells $[7-9]$ and activated macrophages [10]. These beryllium antigen-specific $\mathrm{T}$ cell clones proliferate in response to beryllium [11, 12], while cells from other granulomatous diseases do not $[2,8]$. CBD BAL cells produce a number of cytokines, which probably act as key regulators in granulomatous inflammation [3, 13, 14]. Specifically, beryllium induces high BAL cell production of interferon- $\gamma$ (IFN- $\gamma$ ), and lower levels of interleukin-2 (IL-2) [3]. Interleukin-4 (IL-4), which is important in determining the Th1 versus Th2 cytokine pattern [15], is notably absent from 
CBD BAL cells and is not induced by beryllium stimulation $[3,16]$. While low levels of interleukin-10 (IL-10) are stimulated by beryllium, this cytokine may play a counter regulatory role in $\mathrm{CBD}$, as exogenous IL-10 is able to partially downregulate the production of beryllium-induced cytokines [13]. Finally, the proinflammatory macrophage product tumour necrosis factor- $\alpha$ (TNF- $\alpha)$, which is associated with the development of florid granulomas [17] and interleukin-6 (IL6), which is important in $\mathrm{T}$ cell activation and commitment to a Th2 cytokine profile [18], are highly upregulated in $\mathrm{CBD}$ beryllium-stimulated BAL cells $[10,14]$.

Although the use of BAL has improved understanding of the immune response in this granulomatous disease, it is an invasive procedure and provides only a limited number of cells with which to study the CBD immune response. While BAL is critical in the diagnostic evaluation of a patient with suspected CBD, a less invasive model is desired to study the cellular immune response in CBD. In CBD, berylliumresponsive cells are present in the peripheral blood as evidenced by incorporation of tritiated thymidine upon stimulation with beryllium in the BeLPT [19] and a positive beryllium skin patch test $[20,21]$. Thus, it may be possible to dissect the cellular immune response to beryllium using peripheral blood cells as a model. It is hypothesized that beryllium stimulates a cytokine response from peripheral blood mononuclear cells (PBMNs), in a manner analogous to that found in BAL cells.

Furthermore, it is hypothesized that the berylliuminduced cytokine response can be modulated by crossregulatory cytokines. IL-4 has been used in vivo in animal models of Th1-mediated diseases, including autoimmune encephalitis [22] and inflammatory bowel disease [23], to incite a Th2 predominant cytokine immune response and disease amelioration. It has also been found to reduce inflammation, cellular infiltration, and TNF- $\alpha$ production in murine arthritis [24] and human rheumatoid arthritis PBMNs [25]. In numerous cell models, IL-4 has been found to downregulate proinflammatory cytokines such as $\mathrm{TNF}-\alpha[26,27]$, along with the T cell cytokines IFN- $\gamma$ and IL-2 [28, 29]. Based on these observations, it was hypothesized that absence or low levels of IL-4 present in CBD may help explain the predominant Th1 cytokine response, with high levels of IFN- $\gamma$ and low levels of IL-10. In addition, exogenous recombinant IL-4 would result in a switch to a prominent Th2 cytokine response in vitro.

This study evaluated beryllium-stimulated product of IFN- $\gamma$, IL-2, IL-6, IL-10 and TNF- $\alpha$ in PBMNs from normal and $\mathrm{CBD}$ patients and the ability of recombinant human IL-4 to modulate this antigenspecific cell-mediated immune response in CBD PBMNs and BAL cells.

\section{Materials and methods}

\section{Study populations}

Chronic beryllium disease subjects. CBD was defined by the presence of 1) an abnormal blood beryllium sulphate. $\left(\mathrm{BeSO}_{4}\right)$ lymphocyte proliferation test (BeLPT) and/or BAL BeLPT, indicative of a $\mathrm{BeSO}_{4}$-specific immune response and 2) histological evidence of granulomas or mononuclear cell infiltrates on lung biopsy, usually obtained via transbronchial biopsy [1]. Twentytwo subjects were enrolled into this study who met this case definition and were evaluated in the Occupational and Environmental Medicine Clinic at National Jewish Medical and Research Center (Denver, CO, USA). Thirteen were recruited for the peripheral blood experiments and five for the BAL experiments alone, while four were enrolled in both the peripheral blood and BAL experiments.

Control subjects. Ten control subjects were enrolled into the peripheral blood study, who had no known exposure to $\mathrm{BeSO}_{4}$ and no respiratory symptoms. One individual had mild asthma and was using inhaled corticosteroids.

Informed consent was obtained from all subjects according to our institution's Human Subjects Review Board. Demographic characteristics, including age and sex, smoking status, and use of immunosuppressants, were obtained from all of the CBD cases. A "never smoker" was defined as someone who had smoked fewer than 20 packs of cigarettes in their lifetime (table 1).

\section{Study design}

The cytokine protein response, including IFN- $\gamma$, TNF- $\alpha$, IL-2, IL-10 and IL-6, were assessed over time in unstimulated, beryllium ( $\left.\mathrm{BeSO}_{4}\right)$-stimulated, Salmonella typhimurium lipolysaccharide (LPS) (Sigma, St. Louis, MO, USA) and phytohaemagglutanin-stimulated (PHA) (Sigma) PBMN and BAL cell supernatants. PHA was used as a positive control of $\mathrm{T}$ cell cytokine stimulation, while LPS was used as a positive control of monocyte cytokine stimulation. Recombinant human IL-4 (rHu IL-4) was added for 30-60 min before stimulation with the above agents. Interleukin-4 mRNA was evaluated in the $\mathrm{rHu}$ IL-4 treated unstimulated and $\mathrm{BeSO}_{4}$-stimulated $\mathrm{PBMNs}$ and BAL cells. Timepoints resulting in maximal cytokine levels were used to evaluate the cytokine production in the PBMN and BAL supernatants, because of the complexity of the experimental design and necessity for large cell numbers. Because of limited number and availability of BAL cells, four CBD subjects' cells were used in both the PBMN and BAL experiments; ideally, paired data would have been available on all subjects and controls for both BAL and PBMN cells. The number and type of subjects included in each experiment is indicated in the text and figure legends.

\section{Reagents}

Cell culture reagents used in this study included complete media consisting of Roswell Park Memorial Institute (RPMI) 1640 (Biowittaker, Walkersville, MD, USA), $10 \%$ heat inactivated iron supplemented calf serum (Hyclone, Logan, UT, USA), $0.29 \mathrm{mg} \cdot \mathrm{mL}^{-1}$ 
Table 1.-Demographic characteristics, smoking status, and use of corticosteroids for the subjects enrolled in the peripheral blood and bronchoalveolar lavage studies

\begin{tabular}{|c|c|c|c|}
\hline & \multicolumn{2}{|c|}{ Peripheral blood } & \multirow{2}{*}{ 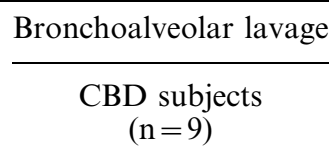 } \\
\hline & $\begin{array}{l}\text { Control subjects } \\
\quad(\mathrm{n}=10)\end{array}$ & $\begin{array}{l}\text { CBD subjects* } \\
\quad(\mathrm{n}=17)\end{array}$ & \\
\hline $\begin{array}{l}\text { Mean } \pm \text { SD age, yr } \\
\text { Sex male/female }\end{array}$ & $\begin{array}{c}34.6 \pm 9.0 \\
4 / 6\end{array}$ & $\begin{array}{c}52.0 \pm 2.0 \\
13 / 4\end{array}$ & $47 \pm 7.0$ \\
\hline \multicolumn{4}{|l|}{ Smoking status $\mathrm{n}$} \\
\hline Never & 9 & 7 & 6 \\
\hline Former & 1 & 9 & 2 \\
\hline Current & 0 & 1 & 1 \\
\hline \multicolumn{4}{|l|}{ Prednisone use } \\
\hline Yes/no & $0 / 10$ & $8 / 9$ & $2 / 7$ \\
\hline Inhaled steroids & & & \\
\hline Yes/no & $1 / 10$ & $4 / 13$ & $4 / 5$ \\
\hline \multicolumn{4}{|l|}{ Other Immunosuppressive therapy } \\
\hline Yes/no & $0 / 10$ & 1/16: Methotrexate & $\begin{array}{l}\text { 2/7: Methotrexate } \\
\text { pentoxifylline }\end{array}$ \\
\hline
\end{tabular}

*: 4 subjects were included in the peripheral blood and bronchoalveolar lavage experiments.

L-glutamine, $100 \mathrm{U} \cdot \mathrm{mL}^{-1}$ penicillin and $100 \mu \mathrm{g} \cdot \mathrm{mL}^{-1}$ streptomycin (Biowittaker, Walkersville, MD). Beryllium sulphate was maintained as stock solutions of 100 and $1000 \mu \mathrm{M} \mathrm{BeSO}$ in water, and diluted 1:10 during cell culture for a final concentration of 10 and $100 \mu \mathrm{M}$. $\mathrm{rHu}$ IL-4 was purchased from R \& D Systems (Minneapolis, MN, USA). The undiluted protein preparation contained $<0.1 \mathrm{ng}$ LPS per $\mu \mathrm{g}$ of undiluted cytokine, as measured by the supplier. PHA and LPS were used as positive controls for $\mathrm{T}$ cell and macrophage cytokine production. All reagents and plasticware used in this study were free of LPS contamination as measured using the Limulus Amebocyte Lysate Assay (Associates of Cape Cod, Woods Hole, MA, USA). The limit of detection of this assay is $0.025 \mu \mathrm{g} \cdot \mathrm{mL}^{-1} \mathrm{LPS}$.

\section{Sample collection}

Peripheral blood mononuclear cells. Venous blood was obtained in heparinized tubes from CBD and control subjects. Mononuclear cells were isolated using Ficoll-Paque (Pharmacia Biotech AB, Uppsala, Sweden) density centrifugation, washed three times in balanced salts solution, and resuspended in complete media as previously described [7, 19]. The mixed cell population was counted and evaluated for cell viability by trypan blue dye exclusion. The cells were resuspended at $2.5 \times 10^{6} \cdot \mathrm{mL}^{-1}$. An automated complete blood cell count and differential were obtained and evaluated by standard commercial laboratory methods for polymorphonuclear leukocytes, lymphocytes, and monocytes. This cell count was used to approximate the cell differential of the PBMNs. These cells provided a simplified model of the mixed BAL cell population (see table 2).

Bronchoalveolar lavage cells. BAL was performed on 9 CBD subjects as previously described [7]. Briefly, aliquots of $60 \mathrm{~mL}$ sterile normal saline, at room temperature, were instilled into a segment of the right middle or lower lobe, for a total of $240 \mathrm{~mL}$ of saline. The fluid was retrieved by gentle hand suctioning and the aliquots of recovered fluid were combined and mixed gently. The BAL fluid and cells were centrifuged at $5000 \times g$ for $10 \mathrm{~min}$ at $4{ }^{\circ} \mathrm{C}$ to form a pellet. The BAL fluid was removed and the mixed cell pellet was resuspended in media. The mixed BAL cells were counted, evaluated for cell viability by trypan blue dye exclusion, and resuspended at $1 \times 10^{6}$ cells $\cdot \mathrm{mL}^{-1}$. Cell differential counts were obtained for lymphocytes, macrophages, eosinophils and neutrophils, and reported as total cell number per $\mathrm{mL}$ and percentages of the total cell count (table 2).

Culture of bronchoalveolar lavage and peripheral blood mononuclear cells. The PBMNs were suspended at $2.5 \times 10^{6}$ cells $\cdot \mathrm{mL}^{-1}$. The BAL cells were suspended at $1 \times 10^{6}$ cells $\cdot \mathrm{mL}^{-1}$. The cells were then cultured in 96 well flat bottom plates (Becton Dickinson, Lincoln Park, NJ, USA) in the presence or absence of 10 or $100 \mu \mathrm{M} \mathrm{BeSO}$ for $0,24,72$, or $120 \mathrm{~h}$ at $37^{\circ} \mathrm{C}$, in $5 \%$ $\mathrm{CO}_{2}$. In some experiments, cells were treated with 10 or $50 \mathrm{ng} \cdot \mathrm{mL}^{-1}$ of $\mathrm{rHu}$ IL-4 for $30-60 \mathrm{~min}$ at $37^{\circ} \mathrm{C}$, in $5 \%$ $\mathrm{CO}_{2}$ before the addition of the $\mathrm{BeSO}_{4}$. The concentration of $\mathrm{rHu}$ IL-4 $[30,31]$ and preincubation [27] time used were based on those found to be effective in altering the Th1 cytokine response in previous studies. Following rHu IL-4 treatment, PBMNs were unstimulated, PHA-stimulated $\left(10 \mu \mathrm{g} \cdot \mathrm{mL}^{-1}\right)$, LPSstimulated $\left(1 \mu \mathrm{g} \cdot \mathrm{mL}^{-1}\right)$ or $\mathrm{BeSO}_{4}$-stimulated $(10$ or $100 \mu \mathrm{M})$. Culture supernatants were harvested at the indicated intervals and the cells removed by centrifugation at $1,500 \mathrm{rpm}$, at room temperature for $5 \mathrm{~min}$. The harvested, cell-free culture supernatants were stored at $-20^{\circ} \mathrm{C}$ until use. The harvested cells were suspended and lysed in $500 \mu \mathrm{L} \cdot \mathrm{L} \times 10^{6}$ cells of $4 \mathrm{M}$ guanidine isothiocyanate (Gibco/BRL, Grand Island, NY, USA) plus 8 per cent (volume per volume) 2mercaptoethanol (Sigma) (GN-2ME). The cell lysates were stored at $-80^{\circ} \mathrm{C}$ until use. 
Table 2. - Blood and bronchoalveolar lavage cell counts, and beryllium lymphocyte proliferation test in chronic beryllium disease (CBD) subjects participating in the peripheral blood and bronchoalveolar lavage studies. Data presented are median (interquartile range)

\begin{tabular}{lcc}
\hline & CBD PBMN group $(\mathrm{n}=17)$ & CBD BAL group $(\mathrm{n}=9)$ \\
\hline Blood peak BeLPT, SI & $5.8(3.2-14.5)$ & $12.6(4.2-91.6)$ \\
Blood WBC count $\left(\times 10^{6} \cdot \mathrm{mL}^{-1}\right)$ & $6.5(4.9-8.0)$ & $6.5(5-7.9)$ \\
Polymorphonuclear leukocyte \% of total & $63.5(57.5-69.5)$ & $65(62-80)$ \\
Lymphocytes \% of total & $27(19.5-29)$ & $7(9-28)$ \\
Monocyte \% of total & $5(3-7)$ & $58.4(7.6-177.1)$ \\
BAL peak BeLPT, SI & $44.6(26.3-174.6)$ & $54.6(37.85-88.5)$ \\
BAL WBC, absolute $\left(\times 10^{6}\right)$ & $56.0(32.3-74.1)$ & $53(36-64.5)$ \\
BAL macrophages \% of total & $53(34-62)$ & $46(33-60)$ \\
BAL lymphocytes \% of total & $46(37.5-65)$ & \\
\hline
\end{tabular}

BeLPT: beryllium lymphocyte proliferation test; SI: stimulation index; WBC: white blood cell; BAL: bronchoalveolar lavage; PBMN: peripheral blood mononuclear cell.

\section{Cytokine measurements in cell culture supernatants}

Quantitative levels of IFN- $\gamma$, IL-2, IL-6, TNF- $\alpha$ and IL-10 cytokines were determined using two-site sandwich enzyme linked immunosorbent assays (ELISA). Quantikine Kits (R \& D Systems) or matched antibody pairs kits (R \& D Systems) were used to measure IFN- $\gamma$, IL-2, IL- 6 and TNF- $\alpha$ per the manufacturers' instructions. The minimum detection limits for these assays were $3.0 \mathrm{pg} \cdot \mathrm{mL}^{-1}, 7.0 \mathrm{pg} \cdot \mathrm{mL}^{-1}, 4.4 \mathrm{pg} \cdot \mathrm{mL}^{-1}$ and $7.8 \mathrm{pg} \cdot \mathrm{mL}^{-1}$ for IFN- $\gamma$, IL-2, TNF- $\alpha$, and IL-6, respectively. The IL-10 ELISA was prepared as an ELISA supplied by Schering-Plough (Kenilworth, NJ, USA). Briefly, a 96 well plate was coated with $1 \mu \mathrm{g} \cdot \mathrm{mL}^{-1}$ protein $\mathrm{G}$ purified rat monoclonal IL-10 antibody (Schering-Plough), incubated at $4^{\circ} \mathrm{C}$ overnight, washed three times with $0.05 \%$ Tween 20 in phosphate buffered saline (PBS), and blocked overnight at $4^{\circ} \mathrm{C}$ in $1 \%$ bovine serum albumin (BSA) with $0.05 \%$ sodium Azide in PBS. One hundred microlitres of sample or standard $\left(625 \mathrm{pg} \cdot \mathrm{mL}^{-1}\right.$ diluted $1: 2$ to $9.76 \mathrm{pg} \cdot \mathrm{mL}^{-1}$ ) was added and incubated overnight at $4{ }^{\circ} \mathrm{C}$. The plate was washed four times as above, and a $1: 2,500$ dilution of immunoglobulin-G (IgG) purified rabbit polyclonal antibody (Schering-Plough) was added for $2 \mathrm{~h}$. The plate was washed four times and $100 \mu \mathrm{L}$ of $1: 10,000$ dilution of peroxidase-conjugated goat anti-rabbit IgG was added for $2 \mathrm{~h}$. The plate was washed four times and $100 \mu \mathrm{L} 3^{\prime}, 5,5^{\prime}$ Tetramethylbenzadine (TMB) substrate solution (BioRad, Herculies, CA, USA) was added for $15 \mathrm{~min}$. The reaction was stopped by adding $50 \mu \mathrm{L}$ of $2 \mathrm{M} \mathrm{H}_{2} \mathrm{SO}_{4}$. The ELISA was read using a dual wavelength of $450 \mathrm{~nm} / 590 \mathrm{~nm}$. The minimum detection limit of the IL-10 ELISA was $10.0 \mathrm{pg} \cdot \mathrm{mL}^{-1}$. Results are presented as the mean of duplicates, expressed in $\mathrm{pg} \cdot \mathrm{mL}^{-1}$ of cytokine.

Quantification of cytokine messenger ribonucleic acid transcripts using reverse transcriptase polymerase chain reaction

Cellular RNA was isolated from the cell lysates in GN-2ME using the Glass MAX RNA microisolation spin cartridge system (Life Technologies, Inc.,
Gaithersburg, MD, USA) as previously described [3]. Reverse transcription was initiated using an oligo dT primer and the avian myoblastosis virus reverse transcriptase in a $20 \mu \mathrm{L}$ reaction (Promega, Madison, WI, USA).

Primers for $\beta$-actin and IL-4 were obtained from Clontech (Palo Alto, CA, USA). The PCR reactions for $\beta$-actin and IL-4 were performed simultaneously for each condition and timepoint, to minimize variability. Positive controls (Clontech) were used for each primer to ensure the specificity of the PCR reaction. Complementary deoxyribonucleic acid (cDNA) was amplified for 35 cycles with $10 \mathrm{~s}$ at $94^{\circ} \mathrm{C}$ for denaturation, $45 \mathrm{~s}$ at $60^{\circ} \mathrm{C}$ for re-annealing, $2 \mathrm{~min}$ at $72^{\circ} \mathrm{C}$ for extension per cycle, and a 7 min final extension phase for both $\beta$-actin and IL-4, as optimized by the manufacturer. For all PCR amplification reactions, the amount of cDNA per reaction was standardized to $2 \mu \mathrm{g}$ as determined using a Beckman DU-64 spectrophotometer (Beckman Instruments, Fullerton, CA, USA). A $50 \mu \mathrm{L}$ PCR reaction, containing $2 \mu \mathrm{g}$ cDNA, $1 \mathrm{mM} \mathrm{MgCl}_{2}, 1 \mathrm{mM}$ deoxyribonucleoside triphosphate (dNTP), $5 \mu \mathrm{L} 10 \times$ Taq PCR buffer (Perkin Elmer, Norwalk, CT, USA), $0.4 \mu \mathrm{M}$ primers, and 2 units of Taq (Perkin Elmer) was used for semiquantitative PCR. For the BAL samples, $2 \mu \mathrm{L}$ of ${ }^{32} \mathrm{P}-\alpha-\mathrm{d}$ cytosine triphosphate (CTP) (New England Nuclear Research Products, Boston, MA, USA) was added to the PCR reactions. Twenty-five $\mu \mathrm{L}$ of the PCR product and $10 \mu \mathrm{L}$ of a 100 base pair ladder (Promega, Madison, WI, USA) was electrophoresed on a $2.0 \%$ (weight/volume) agarose gel and visualized by ethidium bromide $(\mathrm{EtBr})$ staining. The area corresponding to the IL- 4 and $\beta$-actin positive control bands at 344 and 838 base pairs were respectively excised and ${ }^{32} \mathrm{P}-\alpha-\mathrm{d}$ CTP incorporation was measured by scintillation counting. The advent of new methodology employing the fluorescent dye Vistra Green (Amersham Life Science, Buckinghamshire, England) permitted us to substitute a more sensitive detection method to measure IL-4 mRNA in CBD PBMNs. Therefore, the data presented for PBMNs employs Vistra Green staining as described by HAMADA et al. [32]. PBMN cDNA was electrophoresed as above, and the gel incubated at $4^{\circ} \mathrm{C}$ for $1 \mathrm{~h}$ in $0.01 \%$ Vistra 
Green. Fluorescence was detected using a Storm 840 PhosphorImager (Molecular Dynamics, Sunnyvale, CA, USA) and semi-quantitative analysis of the cDNA was performed using Image Quant software (Molecular Dynamics). Ratios of the IL-4 versus $\beta$-actin mRNA using CPM for ${ }^{32} \mathrm{P}-\alpha$-d CTP incorporation or densitometry counts for Vistra Green staining provide semi-quantitative analysis. mRNA methods using ethidium bromide staining detects approximately $1-5 \mathrm{ng}$ of DNA [33], Vistra Green detects approximately $10-20$ pg while ${ }^{32} \mathrm{P}-\alpha-\mathrm{d}$ CTP incorporation is of intermediate sensitivity. These methods have provided comparable results in the authors' laboratory.

\section{Lymphocyte proliferation}

The blood and BAL BeLPTs were performed according to the methods of Mroz et al. [19]. The counts per minute (cpm) from each set of quadruplicates is meaned and expressed as a ratio of the cpm of the beryllium-stimulated cells to the unstimulated cells (stimulation index, (SI)) [19]. The peak SI is reported for PBMN and BAL cells. All test results used in this study were obtained within 12 months of enrollment.

\section{Statistical analysis}

Cytokine responses measured below the minimum detection level of the ELISA were assigned the minimum detectable concentration value and used in the statistical analysis. Because the data were not normally distributed, for purposes of statistical analysis the cytokine levels were log transformed, which provided a more normal distribution. Repeated measures analysis of variance (ANOVA) was used to measure each cytokine response and lymphocyte proliferation separately in each study, across time and treatment condition. When differences across time or condition were found to be significant, Tukey-Kramer multiple comparisons were used to make each pairwise contrast between groups, timepoints and treatment conditions. Cytokine, lymphocyte proliferation and BAL and PBMN cell values are expressed as medians, with interquartile ranges (IQR). Wilcoxon Rank-Sum and Spearman's correlation were used to compare demographic and clinical variables, cell counts and cytokine levels at one time. Statistical significance was defined as $\mathrm{p}<0.05$.

\section{Results}

Beryllium stimulated peripheral blood mononuclear cell proliferation and cytokine responses

We measured the cytokine levels in the culture supernatants of PBMNs from 17 CBD patients and 10 control subjects after stimulation (figs. 1-5) with and without $\mathrm{BeSO}_{4}$. The one control with asthma displayed a similar cytokine response to the remainder of the controls.

Unstimulated PBMNs from CBD and control subjects produced levels of IFN- $\gamma$ and IL-2 at or below the detection limit of the assay over time (figs. 1 and 2). Beryllium sulphate did not stimulate the production of IFN- $\gamma$ or IL-2 from control PBMN cells. However, CBD PBMNs stimulated with $100 \mu \mathrm{M}$ $\mathrm{BeSO}_{4}$ produced elevated levels of IFN- $\gamma$ detected by $24 \mathrm{~h}$, which remained elevated for up to $120 \mathrm{~h}$ of culture (fig. 1). The levels of IFN- $\gamma$ produced at 24 (median $14.0 \mathrm{pg} \cdot \mathrm{mL}^{-1}$ IQR $\left.[3.0-45.5]\right), 72$ $\left(150 \mathrm{pg} \cdot \mathrm{mL}^{-1}[94.2-262.3]\right)$, and $120 \mathrm{~h}\left(325.0 \mathrm{pg} \cdot \mathrm{mL}^{-1}\right.$ [101.6-650.0]), differed significantly over time from that produced by the unstimulated CBD cells $(\mathrm{p}<0.01)$. In CBD PBMNs, $\mathrm{BeSO}_{4}$ stimulated low levels of IL-2, which peaked at $24 \mathrm{~h}\left(23.2 \mathrm{pg} \cdot \mathrm{mL}^{-1}[8.5-46.0]\right)$, and began to decline by $72 \mathrm{~h}\left(13.0 \mathrm{pg} \cdot \mathrm{mL}^{-1}[7.0-73.45]\right)$ returning to baseline levels by $120 \mathrm{~h}\left(7.0 \mathrm{pg} \cdot \mathrm{mL}^{-1}\right.$

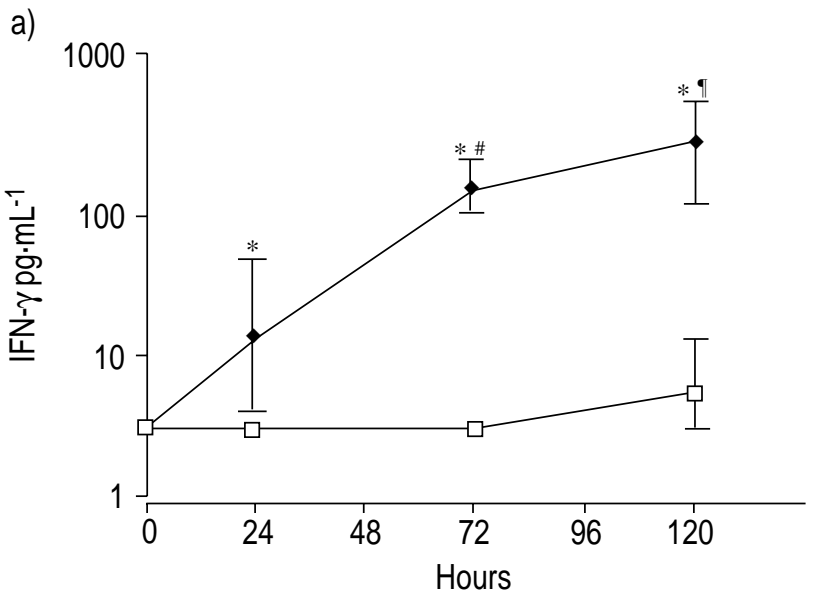

b)

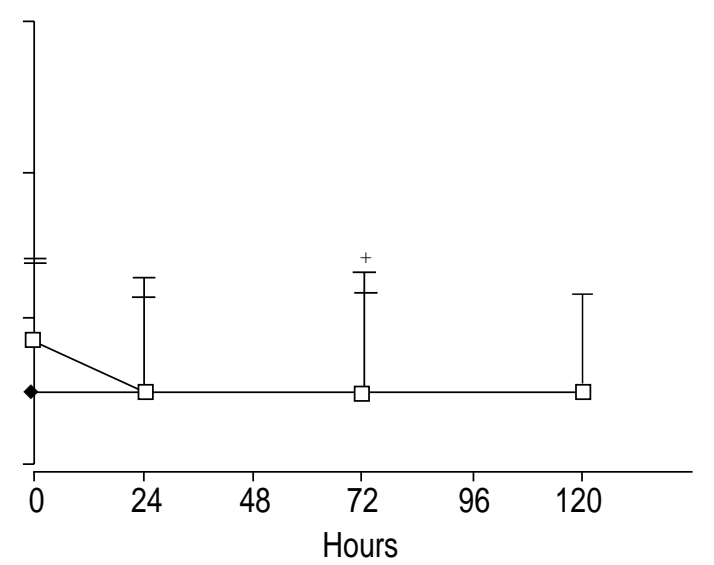

Fig. 1. - Peripheral blood mononuclear cells (PBMNs) were cultured in the absence $(\square)$ or presence $(\downarrow)$ of $100 \mu \mathrm{M}$ beryllium sulphate for up to $120 \mathrm{~h}$. Data presented are medians with interquartile range. a) Beryllium sulphate stimulates significant interferon- $\gamma$ (IFN- $\gamma$ ) from chronic beryllium disease $(\mathrm{CBD})$ PBMNs $(\mathrm{n}=17)$. b) Beryllium sulphate does not stimulate IFN- $\gamma$ from control PBMNs $(\mathrm{n}=10)$. *: denotes a significant difference comparing the unstimulated and beryllium-stimulated PBMNs at the indicated time; $\#$ : indicates a difference between the 24 and $72 \mathrm{~h}$ beryllium-stimulated times; ": indicates a difference between the 24 and $120 \mathrm{~h}$ times. ${ }^{+}$: denotes a significant difference comparing the beryllium-stimulated CBD and control PBMNs $(\mathrm{p}<0.05)$. 
a)

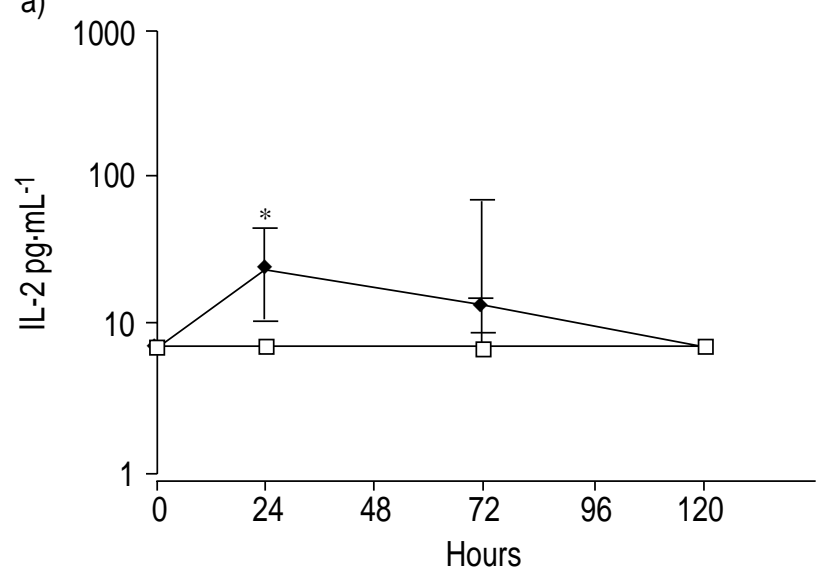

b)

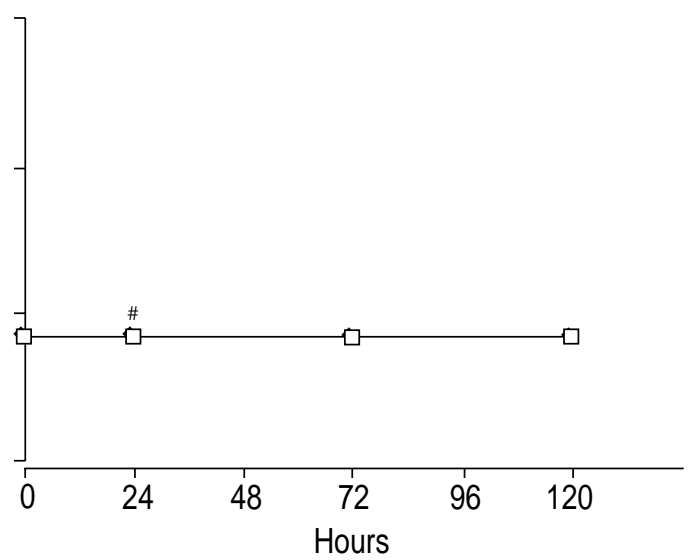

Fig. 2. - Peripheral blood mononuclear cells (PBMNs) were cultured in the absence $(\square)$ or presence $(\$)$ of $100 \mu \mathrm{M}$ beryllium sulphate for up to $120 \mathrm{~h}$. Data presented are medians with interquartile range. a) Beryllium sulphate stimulates significant interleukin-2 (IL-2) from chronic beryllium disease $(\mathrm{CBD})$ PBMNs $(\mathrm{n}=17)$. b) Beryllium does not stimulate IL-2 from control PBMNs $(\mathrm{n}=10)$. *: denotes a significant difference comparing the unstimulated and beryllium-stimulated PBMNs at the indicated time. \#: denotes a significant difference comparing beryllium-stimulated control and CBD PBMNs at the indicated time $(\mathrm{p}<0.05)$.

[7.0-7.0]) (fig. 2). The low median levels partially reflect the lack of IL-2 production by two individuals, as some individuals produced up to $350 \mathrm{pg} \cdot \mathrm{mL}^{-1}$. The levels of IL-2 produced at $24 \mathrm{~h}$ by $\mathrm{BeSO}_{4}$-stimulated CBD PBMNs differed significantly from unstimulated CBD PBMNs $(\mathrm{p}<0.01)$.

Constitutive levels of IL-6 were produced by unstimulated CBD PBMNs by $72-120 \mathrm{~h}$ of culture $\left(33.0 \mathrm{pg} \cdot \mathrm{mL}^{-1}[21.0-184.0]\right)$. This differed significantly from unstimulated control subjects' cells, which produced negligible IL-6 $\left(7.8 \mathrm{pg} \cdot \mathrm{mL}^{-1}\right.$ [7.8-17.0], $\mathrm{p}=0.0002$ ) (fig. 3). Control subjects' PBMNs did not produce significant levels of IL-6 following $\mathrm{BeSO}_{4}$ stimulation. Beryllium sulphate-stimulated release of IL-6 peaked at $24 \mathrm{~h}\left(30.5 \mathrm{pg} \cdot \mathrm{mL}^{-1}[13.0-54.7]\right)$ from CBD PBMNs, and remained elevated up to $120 \mathrm{~h}$ $\left(46.2 \mathrm{pg} \cdot \mathrm{mL}^{-1} \quad[25.1-107.42]\right)$. However, beryllium stimulation only significantly increased the production

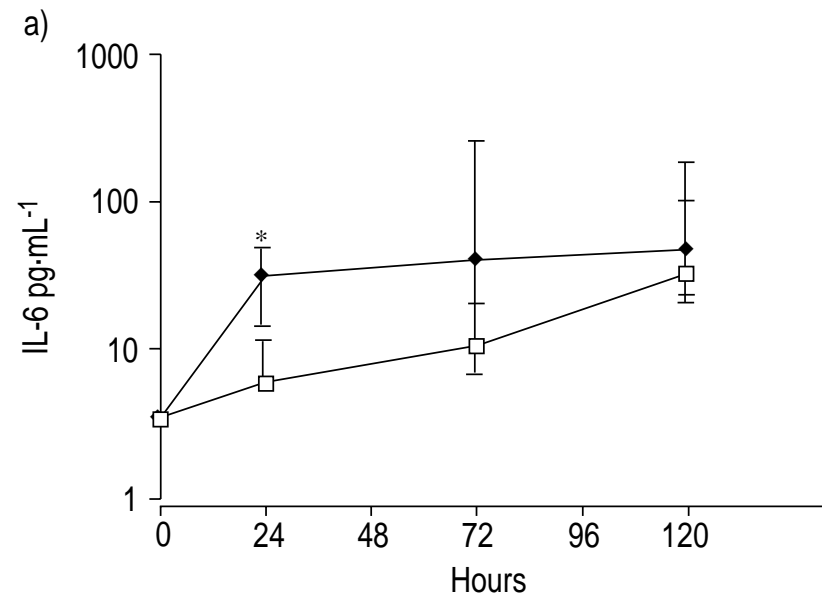

of IL- 6 above constitutive levels in unstimulated CBD PBMNs at $24 \mathrm{~h}\left(7.8 \mathrm{pg} \cdot \mathrm{mL}^{-1}[7.8-12.0], \mathrm{p}=0.045\right)$.

As noted with IL-6, unstimulated CBD PBMNs produced constitutive levels of TNF- $\alpha$ by $72 \mathrm{~h}(30.0$ [10.0-91.9]), which increased further by $120 \mathrm{~h}$ $\left(302.5 \mathrm{pg} \cdot \mathrm{mL}^{-1}[114.8-652.0]\right)$ compared to $24 \mathrm{~h}$ $\left(8.0 \mathrm{pg} \cdot \mathrm{mL}^{-1} \quad[4.4-19.45], \mathrm{p}<0.0001\right)$ (fig. 4). This constitutive production of TNF- $\alpha$ was not a result of endotoxin contamination in culture as determined by the Limulus Amebocyte Lysate Assay. TNF- $\alpha$ was not apparent in unstimulated or stimulated control cells over time. Beryllium sulphate-stimulated TNF- $\alpha$ production from CBD PBMNs increased by $24 \mathrm{~h}$ (59.2 $\left.\mathrm{pg} \cdot \mathrm{mL}^{-1}[12.5-99.5]\right)$, and continued to increase slowly up to $72 \mathrm{~h}\left(166.0 \mathrm{pg} \cdot \mathrm{mL}^{-1}[70.9-273.0]\right)$ and $120 \mathrm{~h}$ of culture $\left(270.0 \mathrm{pg} \cdot \mathrm{mL}^{-1} \quad\right.$ [180.0-383.9], $\mathrm{p}<0.0001$ ). Because of the spontaneous TNF production, the TNF- $\alpha$ expression achieved statistical b)

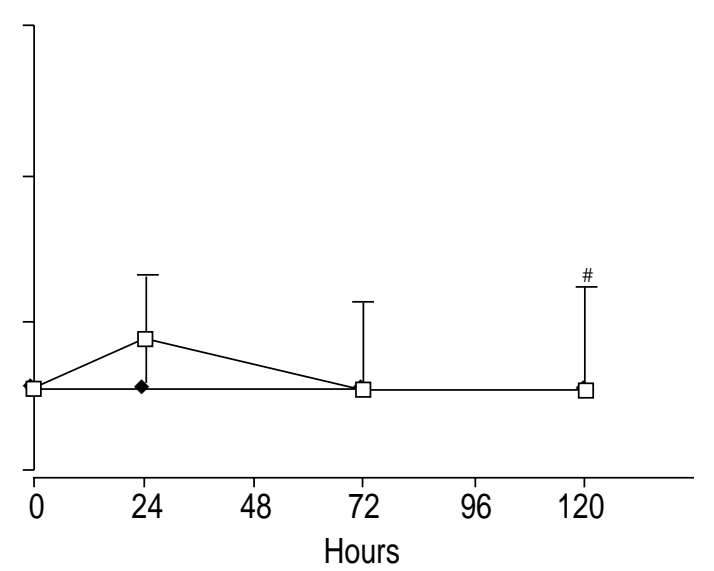

Fig. 3. - Peripheral blood mononuclear cells (PBMNs) were cultured in the absence $(\square)$ or presence $(\$)$ of $100 \mu \mathrm{M}$ beryllium sulphate for up to $120 \mathrm{~h}$. Data presented are medians with interquartile range. a) Beryllium sulphate stimulates significant interleukin-6 (IL-6) from chronic beryllium disease (CBD) PBMNs $(n=9)$. b) Beryllium does not stimulate IL-6 from control PBMNs $(n=10)$. *: denotes a significant difference comparing the unstimulated and beryllium-stimulated PBMNs at the indicated time. ${ }^{\#}$ : denotes a significant difference comparing beryllium-stimulated control and CBD PBMNs at the indicated time $(\mathrm{p}<0.05)$. 
a)

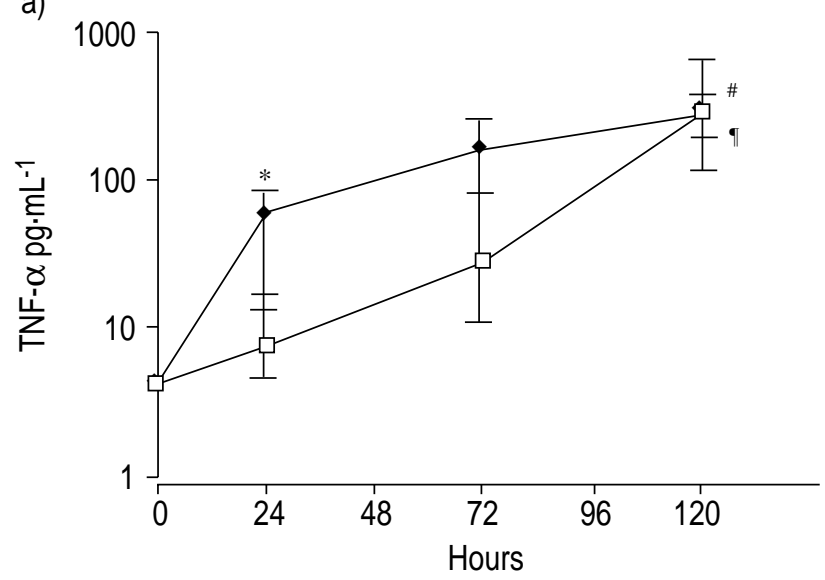

b)

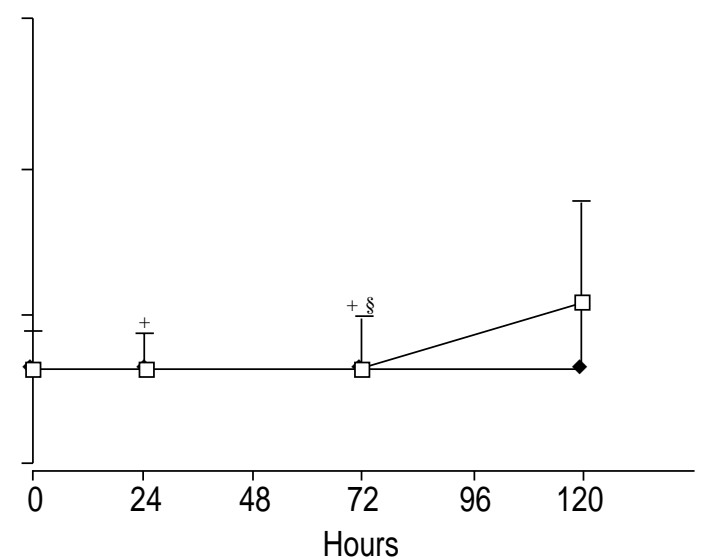

Fig. 4. - Peripheral blood mononuclear cells (PBMNs) were cultured in the absence $(\square)$ or presence $(\$)$ of $100 \mu \mathrm{M}$ beryllium sulphate for up to $120 \mathrm{~h}$. Data presented are medians with interquartile range. a) Beryllium sulphate stimulates significant tumour necrosis factor- $\alpha(\mathrm{TNF}-\alpha)$ from chronic beryllium disease (CBD) PBMNs $(n=17)$. b) Beryllium does not stimulate TNF- $\alpha$ from control PBMNs $(\mathrm{n}=10)$. *: denotes a significant difference comparing the unstimulated and beryllium-stimulated PBMNs at the indicated time; \#: indicates a difference between the 24 and $120 \mathrm{~h}$ beryllium-stimulated times; $\%$ : indicates a difference between the 24 and $120 \mathrm{~h}$ unstimulated times. ${ }^{+}$: denotes a significant difference comparing beryllium-stimulated control and CBD PBMNs at the indicated time; §: indicates a significant difference between unstimulated control and CBD PBMNs $(\mathrm{p}<0.05)$.

significance between unstimulated and $\mathrm{BeSO}_{4}$ stimulated CBD PBMNs at $24 \mathrm{~h}(\mathrm{p}<0.01)$ of culture.

By $120 \mathrm{~h}$ of culture, the unstimulated CBD subjects' PBMNs produced low but elevated levels of IL-10 in culture $\left(25.3 \mathrm{pg} \cdot \mathrm{mL}^{-1}[12.0-40.2], \mathrm{p}<0.01\right)$ compared to the unstimulated control PBMNs (fig. 5). Beryllium sulphate stimulated low but statistically significant IL-10 production from CBD PBMNs at $72 \mathrm{~h}$ only (35.33 $\mathrm{pg} \cdot \mathrm{mL}^{-1}[10.00-77.0]$, compared to the unstimulated CBD cells $\left(10.0 \mathrm{pg} \cdot \mathrm{mL}^{-1} \quad[10.0-39.21]\right.$, $\mathrm{p}=0.02)$. The control subjects did not express any IL-10 above the minimum detection of the ELISA in either unstimulated or $\mathrm{BeSO}_{4}$-stimulated cultures.

Messenger-RNA levels were determined for IL-4. Low levels of IL-4 mRNA were detected in some CBD $(n=5)$ and control PBMNs $(n=6)$, difficult to appreciate on ethidium bromide staining (fig. 6), while no IL-4 was found in others. The IL-4 mRNA, expressed as a ratio of $\beta$-actin production, did not differ over time, with or without beryllium stimulation or between CBD and control PBMNs $(p>0.05)$.

Relation of peripheral blood mononuclear cell cytokine production to demographics, beryllium lymphocyte proliferation test and blood cell count

To determine whether the peak beryllium-stimulated cytokine levels were affected by, or associated with, steroid use, tobacco smoking, peripheral blood cell count or BeLPT (table 2), these characteristics in our CBD cases were compared to IL-2 and TNF- $\alpha$ production at $24 \mathrm{~h}$, and to IFN- $\gamma$ and IL-10 production

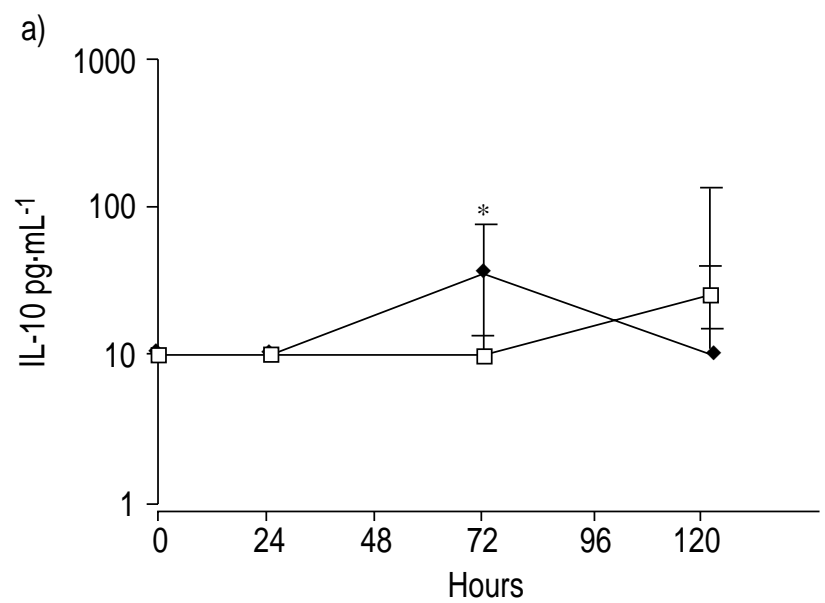

b)

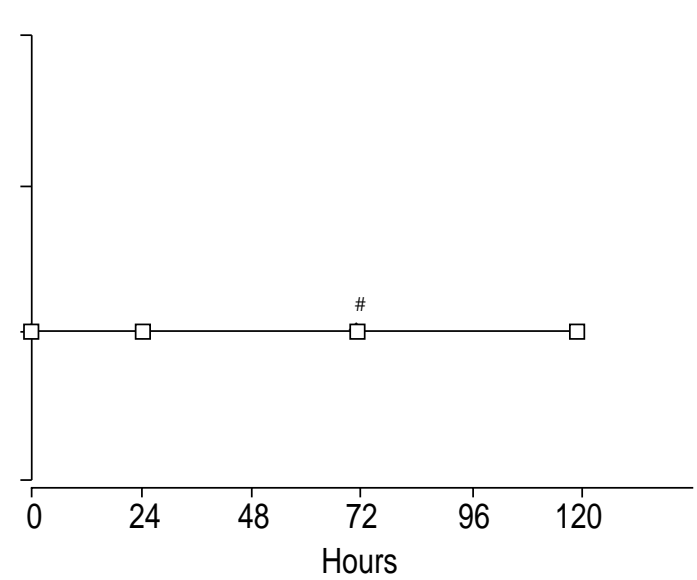

Fig. 5. - Peripheral blood mononuclear cells (PBMNs) were cultured in the absence $(\square)$ or presence $(\downarrow)$ of $100 \mu \mathrm{M}$ beryllium sulphate for up to $120 \mathrm{~h}$. Data presented are medians with interquartile range. a) Beryllium sulphate stimulates significant interleukin-10 (IL-10) from chronic beryllium disease (CBD) PBMNs $(n=10)$. b) Beryllium does not stimulate IL-10 from control PBMNs $(n=10)$. *: denotes a significant difference comparing the unstimulated and beryllium-stimulated PBMNs at the indicated time. \#. denotes a significant difference comparing beryllium-stimulated control and CBD PBMNs at the indicated time $(p<0.05)$. 

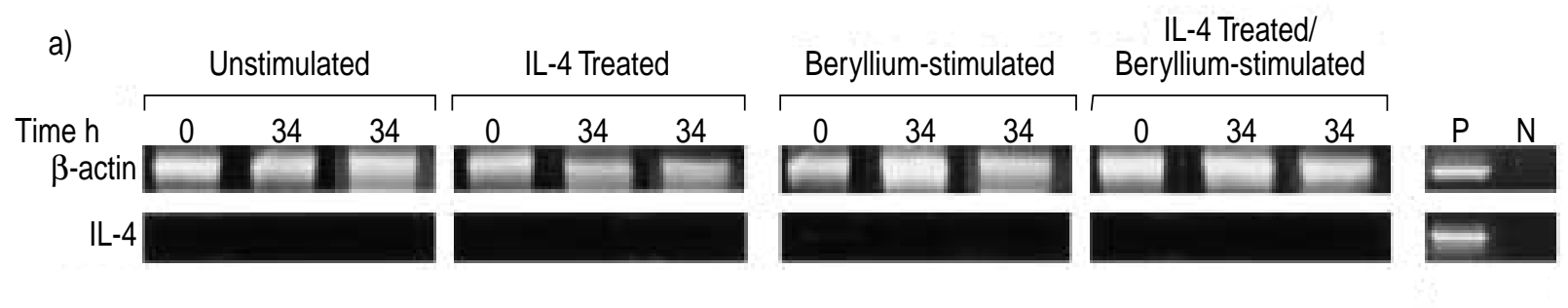

b)

Unstimulated

IL-4 Treated

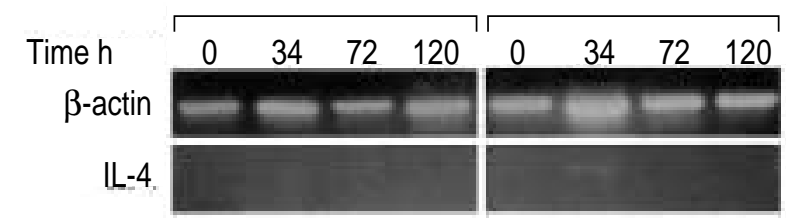

IL-4 Treated/

\begin{tabular}{|llll|llllll}
\hline 0 & 34 & 72 & 120 & 0 & 34 & 72 & 120 & $P$ & $N$ \\
\hline & & & & & & & & & \\
\hline
\end{tabular}

Fig. 6. - Interleukin-4 (IL-4) messenger ribonucleic acid (mRNA) production from chronic beryllium disease (CBD) and control peripheral blood mononuclear cells (PBMNs) and CBD bronchoalveolar lavage (BAL) cells, expressed as a ratio of $\beta$-actin mRNA. Cells were cultured in the presence or absence of beryllium sulphate $(100 \mu \mathrm{M})$ with or without $\mathrm{IL}_{-4}\left(10 \mathrm{ng} \cdot \mathrm{mL}^{-1}\right) \mathrm{pretreatment}$ for up to $120 \mathrm{~h}$ of culture. Total ribonucleic acid was extracted, reverse transcribed and subjected to polymerase chain reaction (PCR). PCR products were analysed on a $2 \%$ agarose gel. a) A representative time course for IL- 4 and $\beta$-actin mRNA from a CBD subject's PBMN cells. Similar results were apparent from other CBD and normal subjects. b) A representative time course for IL-4 and $\beta$-actin mRNA from one CBD subject's BAL cells. Similar results were apparent from the other CBDs' BAL cells. P: positive control; N: negative control.

at $72 \mathrm{~h}$ of culture. Neither steroid use nor smoking were statistically significantly associated with the level of cytokine production. However, a trend was apparent in the levels of TNF- $\alpha$ and steroid use, such that those individuals treated with steroids had lower PBMN TNF- $\alpha$ levels $\left(14.0 \mathrm{pg} \cdot \mathrm{mL}^{-1}[6.8-37.2]\right.$ in steroid users versus $94.5 \mathrm{pg} \cdot \mathrm{mL}^{-1}[15.0-200]$ in nonsteroid users, $\mathrm{p}=0.07)$. A similar trend was apparent for IFN- $\gamma$ $\left(122.1 \mathrm{pg} \cdot \mathrm{mL}^{-1}[6.0-198.8]\right.$ in steroid users versus $200 \mathrm{pg} \cdot \mathrm{mL}^{-1} \quad[99.9-900]$ for nonsteroid users, $\mathrm{p}=0.269)$, IL-2 (14.3 [6.4-25.0] in steroid users versus $38.9 \mathrm{pg} \cdot \mathrm{mL}^{-1}[7.0-162.2]$ for nonsteroid users, $\mathrm{p}=0.144)$, and IL-6 (13.0 [7.0-30.5] in steroid users versus $52.2 \mathrm{pg} \cdot \mathrm{mL}^{-1}$ [21.0-158.9] for nonsteroid users, $\mathrm{p}=0.156$ ), although none met our criterion for statistical significance. The TNF- $\alpha$ production correlated with the peripheral blood BeLPT (Spearman's correlation coefficient $\mathrm{r}=0.54, \mathrm{p}=0.03$ ) and with the peripheral blood monocyte count $(\mathrm{r}=0.58, \mathrm{p}=0.03)$.

Interleukin-4 is unable to downregulate berylliumstimulated cytokines from chronic beryllium disease peripheral blood mononuclear cells

To determine whether IL-4 is able to modulate the $\mathrm{BeSO}_{4}$-stimulated PBMN cytokine response, CBD $(\mathrm{n}=10)$ and control PBMNs $(\mathrm{n}=10)$ were preincubated in the presence or absence of 10 or $50 \mathrm{ng} \cdot \mathrm{mL}^{-1}$ of $\mathrm{rHu}$ IL-4 before stimulation with or without 1) $\mathrm{BeSO}_{4}$ $(100 \mu \mathrm{M}), 2)$ PHA $\left(10 \mu \mathrm{g} \cdot \mathrm{mL}^{-1}\right)$, or 3) LPS $\left(1 \mu \mathrm{g} \cdot \mathrm{mL}^{-1}\right)$. Because of the kinetics noted above, IL-2 and TNF- $\alpha$ production were evaluated after $24 \mathrm{~h}$ and IFN- $\gamma$ and IL-10 after $72 \mathrm{~h}$ of culture. Since similar results were found with both $\mathrm{rHu}$ IL-4 at 10 and $50 \mathrm{ng} \cdot \mathrm{mL}^{-1}$, data were presented using the $10 \mathrm{ng} \cdot \mathrm{mL}^{-1} \mathrm{rHu}$ IL-4 concentration. Stimulation of CBD PBMNs with PHA resulted in significant IL-2 $\left(1,087 \mathrm{pg} \cdot \mathrm{mL}^{-1}\right.$
$[170-2,863]$ at $24 \mathrm{~h}, \mathrm{p}<0.01)$ and IFN- $\gamma$ production $\left(8.927 \mathrm{pg} \cdot \mathrm{mL}^{-1}[6,228-12,548]\right.$ at $\left.72 \mathrm{~h}, \mathrm{p}<0.01\right) \mathrm{com}-$ pared to unstimulated cells. Lipolysaccarhide stimulation produced significant TNF- $\alpha \quad\left(1,420 \mathrm{pg} \cdot \mathrm{mL}^{-1}\right.$ $[1,108-3,671]$ at $24 \mathrm{~h}, \mathrm{p}<0.01)$ and IL-10 $\left(704 \mathrm{pg} \cdot \mathrm{mL}^{-1}[499-1,165]\right.$ at $\left.72 \mathrm{~h}, \mathrm{p}<0.01\right)$ from CBD PBMNs compared to the unstimulated condition. Treatment of PHA-stimulated CBD PBMNs with $\mathrm{rHu}$ IL-4 did not decrease IFN- $\gamma$, production (for PHA alone versus $12,184 \mathrm{pg} \cdot \mathrm{mL}^{-1}[9,706-14,044]$ for $\mathrm{PHA}+\mathrm{rHu}$ IL-4). rHu IL-4 increased PHA-stimulated CBD IL-2 production $\left(2,270 \mathrm{pg} \cdot \mathrm{mL}^{-1}\right.$ [944-3,922], $\mathrm{p}<0.01)$ and reduced LPS-stimulated TNF- $\alpha$ from CBD PBMNs (463 pg. $\mathrm{mL}^{-1}$ [402-1,941], $\left.\mathrm{p}=0.01\right)$. Levels of IL-10 stimulated by LPS were not significantly affected by the addition of rHu IL-4 ( $p>0.05)$. No difference was observed in the production of any of the cytokines by CBD (table 3 ) or control PBMNs with the addition of $\mathrm{rHu}$ IL-4 alone, at a concentration of $10 \mathrm{ng} \cdot \mathrm{mL}^{-1}$. Furthermore, pretreating the $\mathrm{BeSO}_{4-}$ stimulated CBD and control PBMNs with rHu IL-4 did not affect the production of IL-2 or TNF- $\alpha$ at $24 \mathrm{~h}$ of culture, or IFN- $\gamma$ at $72 \mathrm{~h}$ of culture. The median IL-10 production from CBD PBMNs increased by $100 \%$ after pretreatment with $\mathrm{rHu}$ IL-4, although this was not statistically significant $(\mathrm{p}>0.05)$. Finally, no significant increase in IL-4 mRNA was found with $\mathrm{rHu}$ IL-4 pretreatment of unstimulated or $\mathrm{BeSO}_{4}^{-}$ stimulated control or CBD PBMNs over time ( $>0.05$, table 4 , fig. 6).

Because previous studies have shown that immunomodulation by cytokines may be dependent on the antigen concentration [34, 35], we examined the dose response to $\mathrm{BeSO}_{4}$ in $\mathrm{PBMN}$ cells from CBD patients $(\mathrm{n}=10)$. The PBMNs were pretreated with $\mathrm{rHu}$ IL-4 at 0,10 or $50 \mathrm{ng} \cdot \mathrm{mL}^{-1}$ and then stimulated in the presence or absence of 10 and $100 \mu \mathrm{M} \mathrm{BeSO}_{4}$. 
Table 3. - Effect of treatment with recombinant human ( $\mathrm{rHu}$ ) interleukin-4 (IL-4) at $10 \mathrm{ng} \cdot \mathrm{mL}^{-1}$ on chronic beryllium disease $(C B D)$ peripheral blood $(n=10)$ and bronchoalveolar lavage $(B A L)$ cells $(n=9)$ cytokine production. Data presented are median (IQR) at 24 or $72 \mathrm{~h}$ of culture

\begin{tabular}{|c|c|c|c|c|}
\hline \multirow{2}{*}{$\begin{array}{l}\text { Cytokine }\left(\mathrm{pg} \cdot \mathrm{mL}^{-1}\right) \\
\text { Blood }\end{array}$} & \multicolumn{4}{|c|}{ Condition } \\
\hline & Unstimulated & $\begin{array}{c}\mathrm{rHu} \mathrm{IL-4} \\
\left(10 \mathrm{ng} \cdot \mathrm{mL}^{-1}\right)\end{array}$ & $\begin{array}{c}\mathrm{BeSO}_{4} \\
(100 \mu \mathrm{M})\end{array}$ & $\begin{array}{c}\mathrm{rHu} \text { IL-4 } \\
\left(10 \mathrm{ng} \cdot \mathrm{mL}^{-1}\right) / \mathrm{BeSO}_{4}(100 \mu \mathrm{M})\end{array}$ \\
\hline $\begin{array}{l}\text { IFN- } \gamma^{\#} \\
\text { IL-2* } \\
\text { TNF- } \alpha^{*} \\
\text { IL-10 }\end{array}$ & $\begin{array}{c}4.7(3.0-14.1) \\
7.0(7.0-7.0) \\
8.8(4.4-19.5) \\
22.2(10.0-39.2)\end{array}$ & $\begin{array}{c}6.8(3.0-15.1) \\
7.0(7.0-7.0) \\
6.6(4.4-14.0) \\
28.7(10.0-56.9)\end{array}$ & $\begin{aligned} & 215.8(94.2-886.8) \\
& 19.9(25.9-38.9) \\
& 30.7(14.7-177.0) \\
& 42.7(26.5-97.6)\end{aligned}$ & $\begin{array}{c}235.5(80.9-880.1) \\
32.4(8.5-58.8) \\
18.8(13.0-139.7) \\
92.4(71.9-129.6)\end{array}$ \\
\hline \multicolumn{5}{|l|}{ BAL } \\
\hline $\begin{array}{l}\text { IFN- } \gamma^{\#} \\
\text { IL-2* } \\
\text { TNF- } \alpha^{*} \\
\text { IL-10 }\end{array}$ & $\begin{aligned} 13.9 & (3.7-34.9) \\
7.0 & (7.0-7.0) \\
85.7 & (50.5-495.7) \\
25.1 & (10.0-10.0)\end{aligned}$ & $\begin{aligned} & 7.8(3.9-35.4) \\
& 7.0(7.0-7.0) \\
& 96.0(28.0-330.7) \\
& 28.7(10.0-56.9)\end{aligned}$ & $\begin{aligned} 2472 & (1754.1-8488.5) \\
485 & (267.0-1060.5) \\
3195.0 & (1312.5-6513.0) \\
200 & (18.8-1202.0)\end{aligned}$ & $\begin{aligned} 3524 & (1135.7-7813.3) \\
543 & (217.0-1039.5) \\
2256 & (1457.5-7505.3) \\
475 & (31.6-1474.0)\end{aligned}$ \\
\hline
\end{tabular}

*: At $24 \mathrm{~h}$ of culture. ${ }^{\#}$ : At $72 \mathrm{~h}$ of culture. $\mathrm{BeSO}_{4}$ : beryllium sulphate; IFN- $\gamma$ : interferon- $\gamma$; IL-2: interleukin-2; TNF- $\alpha$ : tumour necrosis factor- $\alpha$; IL-10: interleukin-10.

Although not statistically significant, the median level of IFN- $\gamma$ stimulated from CBD PBMNs by $10 \mu \mathrm{M}$ $\mathrm{BeSO}_{4}$ alone $\left(57.4 \mathrm{pg} \cdot \mathrm{mL}^{-1}[20.7-231.0]\right)$ was $75 \%$ lower than those stimulated by $100 \mu \mathrm{M} \quad \mathrm{BeSO}_{4}$ (215.8 $\left.\mathrm{pg} \cdot \mathrm{mL}^{-1}[94.2-886.8]\right)$ at $72 \mathrm{~h}$. Beryllium sulfate at $10 \mu \mathrm{M}$ did not stimulate TNF- $\alpha$ from CBD PBMNs above that produced by unstimulated PBMNs. Similar supernatant levels of IL-2 $\left(10.0 \mathrm{pg} \cdot \mathrm{mL}^{-1}[7.1-23.9]\right.$ with $10 \mu \mathrm{M} \quad \mathrm{BeSO}_{4}$ stimulation) and IL-10 (43.3 $\mathrm{pg} \cdot \mathrm{mL}^{-1}[8.1-100.8]$ with $10 \mu \mathrm{M} \mathrm{BeSO}{ }_{4}$ stimulation) were induced by both concentrations of $\mathrm{BeSO}_{4}$. At $10 \mu \mathrm{M} \mathrm{BeSO}_{4}$, the IFN- $\gamma$ production was unaffected by the addition of $\mathrm{rHu}$ IL-4 $10 \mathrm{ng} \cdot \mathrm{mL}^{-1}\left(180.8 \mathrm{pg} \cdot \mathrm{mL}^{-1}\right.$ [40.8 - 219.9]). A similar increase in IL-10 was seen with rHu IL-4 plus $10 \mu \mathrm{M} \mathrm{BeSO}$ treatment $\left(88.9 \mathrm{pg} \cdot \mathrm{mL}^{-1}\right.$ [73.7-108.9]), as with rHuIL-4 and $100 \mu \mathrm{M} \mathrm{BeSO}$. The addition of $\mathrm{rHu}$ IL-4 did not affect the production of IL-2 or TNF- $\alpha$ in the presence of $10 \mu \mathrm{M} \mathrm{BeSO}$.

Interleukin-4 is unable to downregulate berylliumstimulated cytokines from chronic beryllium disease bronchoalveolar lavage cells

It was questioned whether $\mathrm{rHu}$ IL-4's inability to modulate the cytokine response in CBD PBMNs was a result of the 10-100 fold lower cytokine response from PBMN compared to BAL cells [3, 13, 14]. To examine these issues, CBD BAL cells were pretreated with 10 or $50 \mathrm{ng} \cdot \mathrm{mL}^{-1}$ of $\mathrm{rHu}$ IL-4 for $30-60 \mathrm{~min}$ before stimulation with or without $100 \mu \mathrm{M} \mathrm{BeSO}_{4}$, as outlined above. The data derived from pretreatment with 10 or $50 \mathrm{ng} \cdot \mathrm{mL}^{-1} \mathrm{rHu}$ IL-4 were similar. Therefore, the data are presented for the cultures using $\mathrm{rHu}$ IL-4 at $10 \mathrm{ng} \cdot \mathrm{mL}^{-1}$ (table 3 ).

As has been previously reported and similar to the CBD PBMN response, negligible levels IFN- $\gamma$ or IL-2 were found, and only low levels of TNF- $\alpha$ and IL-10 produced in the media-only supernatants from CBD BAL cells (see table 3 ) $[3,13,14]$. Our previous findings that $\mathrm{BeSO}_{4}$ stimulates IFN- $\gamma$ production 10 times higher than that from CBD PBMNs were also confirmed. Similar to the PBMN response, the IFN- $\gamma$ production peaked at $72 \mathrm{~h}$ of culture $(\mathrm{p}<0.0001$ compared to the media-only condition) and began to decline by $120 \mathrm{~h}$. Beryllium stimulated low IL-2 levels, 20 times higher than that from CBD PBMNs, which peaked at $24 \mathrm{~h}(\mathrm{p}<0.001$ compared to media-only condition) and then declined over 72 and $120 \mathrm{~h}$ of culture. TNF- $\alpha$ levels, $50-100$ fold higher than those from CBD PBMNs, peaked at $24 \mathrm{~h}$ $(\mathrm{p}<0.0001$ compared to unstimulated condition) and

Table 4. - Effect of treatment with recombinant human ( $\mathrm{rHu}$ ) interleukin-4 (IL-4) $\left(10 \mathrm{ng} \cdot \mathrm{mL}^{-1}\right)$ on chronic beryllium disease (CBD) $(n=5)$ and control peripheral blood cells' IL-4 messenger ribonucleic acid (mRNA) production. IL-4 mRNA is expressed as a ratio of IL-4/ $\beta$-actin mRNA. Data are presented as median (IQR) over time

\begin{tabular}{|c|c|c|c|c|}
\hline \multicolumn{3}{|l|}{ IL-4/ $\beta$-actin mRNA ratio } & \multicolumn{2}{|l|}{ Condition } \\
\hline CBD & Unstimulated & $\begin{array}{l}\mathrm{rHu} \mathrm{IL-4} \\
10 \mathrm{ng} \cdot \mathrm{mL}^{-1}\end{array}$ & $\begin{array}{l}\mathrm{BeSO}_{4} \\
100 \mu \mathrm{M}\end{array}$ & $\mathrm{rHu}$ IL-4 $10 \mathrm{ng} \cdot \mathrm{mL}^{-1} / \mathrm{BeSO}_{4}(100 \mu \mathrm{M})$ \\
\hline $0 \mathrm{~h}$ & $0.03(0.01-0.13)$ & $0.14(0.01-0.35)$ & $0.08(0.01-0.17)$ & $0.02(0.01-0.18)$ \\
\hline $24 \mathrm{~h}$ & $0.01(0-0.04)$ & $0(0-0.08)$ & $0(0.03-0.10)$ & $0.02(0.01-0.04)$ \\
\hline $72 \mathrm{~h}$ & $0.01(0-0.05)$ & $0.03(0.01-0.05)$ & $0.05(0.02-0.07)$ & $0.04(0.01-0.11)$ \\
\hline Control* & & & & \\
\hline $24 \mathrm{~h}$ & $0.01(0-0.15)$ & $0(0-0.08)$ & $0(0-0.03)$ & $0.01(0-0.09)$ \\
\hline $72 \mathrm{~h}$ & $0.02(0-0.17)$ & $0.01(0-0.12)$ & $0.01(0-0.17)$ & $0.01(0-0.13)$ \\
\hline
\end{tabular}

*: Data from the 0 timepoint is not available. $\mathrm{BeSO}_{4}$ : beryllium sulphate. 
Table 5. - Effect of treatment with recombinant human ( $\mathrm{rHu}$ ) interleukin-4 (IL-4) $\left(10 \mathrm{ng} \cdot \mathrm{mL}^{-1}\right)$ on chronic beryllium disease $(\mathrm{CBD})(\mathrm{n}=5)$ bronchoalveolar lavage (BAL) cells' IL-4 messenger ribonucleic acid (mRNA) production. IL-4 mRNA is expressed as a ratio of IL-4/ $\beta$-actin mRNA. Data presented as median (IQR) over time

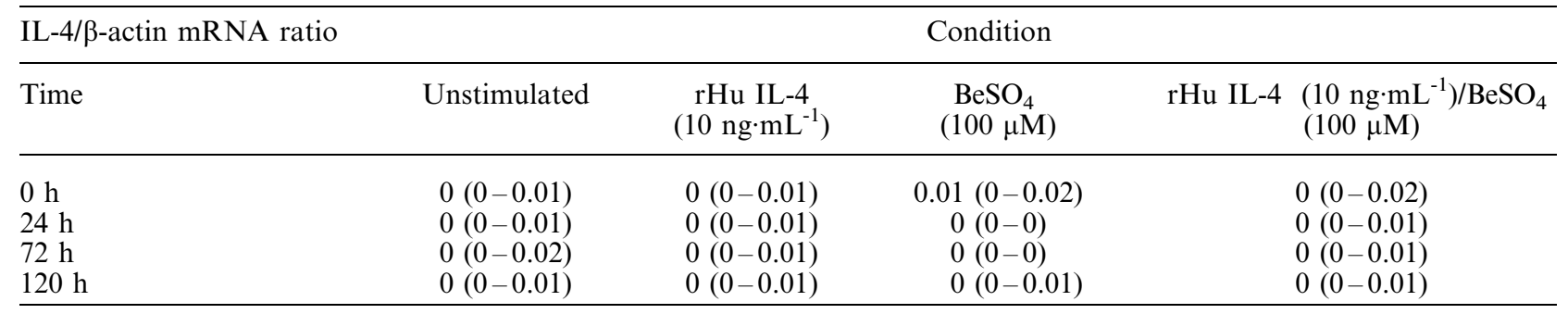

$\mathrm{BeSO}_{4}$ : Beryllium sulphate.

remained elevated at 72 and $120 \mathrm{~h}$ of culture. Beryllium-stimulated IL-10 production peaked at $72 \mathrm{~h}(\mathrm{p}=0.009$ compared to media-only culture) and declined by $120 \mathrm{~h}$ with a similar time response to CBD PBMNs, but with a 5-fold higher level. Part of the difference in the beryllium-stimulated BAL cytokine response compared with $\mathrm{PBMN}$ response may be the different number and types of cells present in the BAL cells (53\% monocytes and 46\% lymphocytes) compared to the PBMN cells (5-7\% macrophages and $22-27 \%$ lymphocytes) (table 2). We found no appreciable IL-4 mRNA in unstimulated or $\mathrm{BeSO}_{4}$-stimulated BAL cells (fig. 6, table 5).

The production of these cytokines at peak timepoints was not associated with steroid use or smoking status. The percentage of BAL lymphocytes was positively correlated with the production of IFN- $\gamma$ (Spearman's correlation coefficient $\mathrm{r}=0.78, \mathrm{p}=0.01), \quad \mathrm{TNF}-\alpha$ $(\mathrm{r}=0.70, \mathrm{p}=0.04)$, and IL-10 $(\mathrm{r}=0.81, \mathrm{p}<0.011)$. The peak BAL BeLPT was also positively associated with IL-10 production $(\mathrm{r}=0.85, \mathrm{p}<0.01)$, while a trend was apparent with IFN- $\gamma$ production $(r=0.65$, $\mathrm{p}=0.06$ ). The addition of $\mathrm{rHu}$ IL-4 to the unstimulated BAL cell cultures did not affect the production of any of these four cytokines at any timepoint. The results for IFN- $\gamma$, IL-2, TNF- $\alpha$, and IL-10 are shown at the peak level in table 3. Furthermore, rHu IL-4 failed to significantly downregulate the production of berylliumstimulated IFN- $\gamma$, IL-2, and TNF- $\alpha$ or to upregulate beryllium-stimulated IL-10 production or IL-4 mRNA (fig. 6, table 5) at any time.

\section{Discussion}

The current findings indicate that $\mathrm{BeSO}_{4}$-stimulated PBMNs from individuals with CBD produce a cytokine profile similar in pattern, but not magnitude of response, to that observed from $\mathrm{BeSO}_{4}$-stimulated CBD BAL cells $[3,13,14]$. The emerging pattern is consistent with the presence of cell populations in the blood and in BAL that are compelled to produce IFN- $\gamma$ and IL-2, along with TNF- $\alpha$, IL-6 and IL-10. Although IL-4 mRNA can be detected in some CBD PBMNs, these cells lack the ability to respond to beryllium with an increase in IL-4, and the levels of IL-4 mRNA are much less than that seen in other antigen stimulated models. Furthermore, high levels of exogenous IL-4 are incapable of limiting the $\mathrm{BeSO}_{4}$-stimulated cytokine production, even when the concentration of antigen is reduced significantly. A major goal in dissecting the beryllium-induced cytokine profile in CBD is to allow us to identify possible immunomodulatory agents in vitro. In the granulomatous disease CBD, IL-4 is unable to alter the cytokine response to beryllium.

Previously, it has been possible to partially modify the cytokine response and $\mathrm{T}$ cell proliferation to beryllium by neutralizing IL-2 with anti-IL-2 antibody [3] and by the addition of exogenous rHu IL-10 to CBD BAL cells [13]. In the current study, in order to maximize the ability to inhibit the beryllium-stimulated cytokine response, cells were pretreated with two concentrations of $\mathrm{rHu}$ IL-4 [30, 31] before antigen stimulation [27], both of which were effective in altering the cytokine production in LPS-stimulated cells [27, 36] and other cells systems in previous studies [25, 30, 31, 35]. Interestingly, $\mathrm{rHu}$ IL-4 $\left(10 \mathrm{ng} \cdot \mathrm{mL}^{-1}\right)$ was capable of downregulating LPS-stimulated TNF- $\alpha$ production from CBD cells, which would indicate that a sufficient IL-4 concentration had been used to modulate cytokine response. However, contrary to our expectation from previous in vitro studies, rHu IL-4 did not reduce beryllium-stimulated IFN- $\gamma$, IL-2 [28, 29] or TNF- $\alpha$ production $[26,27]$ in either CBD BAL or PBMN cells. Furthermore, CBD BAL and PBMN IL-4 mRNA was not increased by treatment with $\mathrm{rHu}$ IL-4. Of note, the addition of IL-4 did increase albeit low levels of beryllium-stimulated IL-10 from blood cells as has been found in other studies [37]. This might indicate recruitment of a naïve Th0 cell population. No increase in the production of IL-10 in CBD BAL cells treated with $\mathrm{rHu}$ IL-4 was found, potentially indicating that a naïve $\mathrm{T}$ cell component is not present, or present at a lower level in BAL cells.

Antigen concentration influences the cytokine response stimulated by antigen [34, 35]. To enhance IL-4 immunomodulatory capabilities, a lower dose of beryllium was tested, but still could not alter the IL-4 response. The findings in BAL and PBMN cells would indicate that once beryllium hypersensitivity is established, it cannot be readily reversed by IL-4. This has been found in other cell [30] and animal models [22]. Although IL-4 ameliorated a Th1 autoimmune encephalitis in mice, a reduction in IL-2, IFN- $\gamma$ or TNF- $\alpha$ was not apparent in the periphery [22]. It is likely that CBD BAL cells and PBMNs have been exposed to beryllium in some form in vivo, prior to restimulation in vitro. Thus, CBD blood and BAL cells are probably already 
primed and committed to this cytokine profile, which may explain IL-4's inability to modify cytokine response in PBMN and BAL cells. It cannot be excluded, that longer pretreatment, or a higher dose of IL-4, might have immunomodulatory capabilities. However, the present data does not suggest that IL-4 is likely to be useful as an immunotherapeutic.

The relationship between clinical parameters such as tobacco use, steroid use, and peripheral blood cell count and blood cytokine levels was evaluated. Although not statistically significant, a decrease in the blood cytokine levels (except IL-10) was noted in the individuals treated with steroids. Similar results have been found from sarcoidosis BAL cells for TNF- $\alpha$ [5] and IFN- $\gamma$ [38], indicating that corticosteroids are able to modify the immune response in these disease processes. Furthermore, these findings substantiate the use of blood cells to evaluate future immunotherapeutics. No association between the peripheral white blood cell counts and beryllium-stimulated blood cytokines was found, probably because most of our CBD cases had normal blood cell counts. It is speculated that blood T cells stimulated with beryllium produce IFN- $\gamma$, IL-2, IL-6 and IL-10, while the blood macrophage or monocyte is responsible for TNF- $\alpha$. It is possible that monocytes produce IL-10 and IL-6 in CBD. Future studies involving separation of $\mathrm{T}$ cell and monocyte populations will be necessary to address which cell type(s) produce which cytokines. Finally, although BAL cell IL-2 is partially responsible for CBD BAL cell proliferation [3], no correlation between cytokine levels and blood BeLPT was found. This may be because cellular proliferation does not result from a single cytokine, but is instead multifactorial. The association between other clinical parameters, such as pulmonary function testing, and cytokine production was not evaluated because of limited power with a small sample size. However, use of PBMNs to evaluate cytokine response to beryllium in the future will allow study of a larger number of CBD subjects and comparisons between cytokine production and clinical disease parameters.

Despite general concordance in CBD blood and BAL cell cytokine response to beryllium, several potentially important differences were noted. Most importantly, the magnitude of response was much lower in CBD PBMNs than in CBD BAL cells. There are several possible explanations for this observation. Different types and numbers of cytokine-producing cells are present in the periphery compared to the lung compartment, as evidenced by the difference in lymphocyte and macrophage/monocyte percentages in table 2. The antigen presenting cells in blood, such as peripheral monocytes or dendritic cells, probably differ from the alveolar macrophages and dendritic cells present in BAL, in their ability to stimulate $\mathrm{T}$ cells and produce cytokines themselves [31, 39, 40]. The number of cells previously "exposed" or committed to beryllium are likely to be fewer in peripheral blood cells, as suggested by the lower proliferative response from PBMNs compared to BAL cells [9]. To further optimize PBMN cytokine production in the future, consideration may be given to increasing the number of monocytes and lymphocytes to approximate that in the BAL. Interestingly, a higher spontaneous production of IL- 6 and TNF- $\alpha$ from CBD PBMNs than controls was found. Thus, the production of these cytokines was not a cell culture phenomenon. Previously, a comparable spontaneous TNF- $\alpha$ production from CBD and control BAL cells [13, 14] was found. Sarcoidosis blood and BAL cells produce spontaneous TNF- $\alpha[4,5]$. This might indicate that CBD blood mononuclear cells are already primed to produce these cytokines before they are even stimulated with beryllium in vitro.

In summary, chronic beryllium disease blood cells produce a cytokine pattern when stimulated with beryllium that is similar to that observed in chronic beryllium disease bronchoalveolar lavage. The bronchoalveolar lavage response is of higher magnitude, and further study may be required to optimize the peripheral blood mononuclear cell response. However, chronic beryllium disease peripheral blood mononuclear cells provide a good model of the berylliumstimulated immune response without the risks and disadvantages of bronchoalveolar lavage. Specifically, the production of the cytokines interferon- $\gamma$, tumour necrosis factor- $\alpha$, interleukin-6, and low levels of interleukin-2 and interleukin-10 was found to be similar to that from bronchoalveolar lavage cells. From the above data, the absence or low levels of interleukin-4 messenger ribonucleic acid present in chronic beryllium disease peripheral blood mononuclear cell bronchoalveolar lavage cells does not appear to be sufficient to result in this cytokine profile, as the addition of interleukin- 4 is unable to modify this response. It is unlikely that interleukin-4 will provide specific immunotherapy for chronic beryllium disease. This peripheral blood mononuclear cell model can be used to investigate other potential immunotherapeutics, which are needed clinically to treat these patients. Using this model may allow continued evaluation of the role of beryllium as an antigen or hapten in the development of beryllium sensitization and chronic beryllium disease, and to understand better how beryllium is able to indirectly or directly affect regulation of these cytokines.

\footnotetext{
Acknowledgements. The authors would like to thank the patients who have made this research possible and helped further understanding of the immune mechanisms in chronic beryllium disease; Heather Davis and Malkah Tannenbaum for expert secretarial assistance; Elaine Daniloff, Masters of Science in Public Health and Colleen Doherty for technical assistance and support.
}

\section{References}

1. Maier LA, Newman LS. Beryllium Disease. In: Rom WN, ed. Environmental and Occupational Medicine. Philadelphia: Lippincott-Raven, 1998: 1017-1031.

2. Newman LS, Kreiss K, King TE Jr, Seay S, Campbell PA. Pathologic and immunologic alterations in early stages of beryllium disease. Am Rev Respir Dis 1989; 139: $1479-1486$. 
3. Tinkle SS, Kittle LA, Schumacher BA, Newman LS. Beryllium induces IL-2 and IFN- $\gamma$ in berylliosis. J Immunol 1997; 158: 518-526.

4. Prior C, Knight RA, Herold M, Ott G, Spiteri MA. Pulmonary sarcoidosis: patterns of cytokine release in vitro. Eur Respir J 1996; 9: 47-53.

5. Baughman RP, Strohofer SA, Buchsbaum J, Lower EE. Release of tumor necrosis factor by alveolar macrophages of patients with sarcoidosis. J Lab Clin Med 1990; 115: 36-42.

6. Inoue Y, Barker E, Daniloff E, Kohno N, Hiwada K, Newman LS. Pulmonary epithelial cell injury and alveolar-capillary permeability in berylliosis. $\mathrm{Am}$ J Respir Crit Care Med 1997; 156: 109-115.

7. Newman LS, Bobka C, Schumacher B, et al. Compartmentalized immune response reflects clinical severity of beryllium disease. Am J Respir Crit Care Med 1994; 150: 135-142.

8. Saltini C, Winestock K, Kirby M, Pinkston P, Crystal RG. Maintenance of alveolitis in patients with chronic beryllium disease by beryllium-specific helper $\mathrm{T}$ cells. $N$ Engl J Med 1989; 320: 1103-1109.

9. Rossman MD, Kern JA, Elias JA, et al. Proliferative response of bronchoalveolar lymphocytes to beryllium. Ann Intern Med 1988; 108: 687-693.

10. Bost TW, Riches DWH, Schumacher B, et al. Alveolar macrophages from patients with beryllium disease and sarcoidosis express mRNA for TNF- $\alpha$ and IL-6 but not IL-1ß. Am J Respir Cell Mol Biol 1994; 10: $506-$ 513.

11. Fontenot AP, Kotzin BL, Comment CE, Newman LS. Expansions of T-cell subsets expressing particular T-cell receptor variable regions in chronic beryllium disease. Am J Respir Cell Mol Biol 1998; 18: $581-589$.

12. Fontenot AP, Falta MT, Freed BM, Newman LS, Kotzin BL. Identification of pathogenic $T$ cells in patients with beryllium-induced lung disease. J Immunol 1999; 163: 1019-1026.

13. Tinkle SS, Kittle LA, Newman LS. Partial IL-10 inhibition of the cell-mediated immune response in chronic beryllium disease. J Immunol 1999; 163: 2747 2753.

14. Tinkle SS, Newman LS. Beryllium-stimulated release of tumor necrosis factor- $\alpha$, interleukin- 6 , and their soluble receptors in chronic beryllium disease. Am J Respir Crit Care Med 1997; 156: $1884-1891$.

15. Nakamura T, Lee RK, Nam SY, Podack ER, Bottomly K, Flavell RA. Roles of IL- 4 and IFN- $\gamma$ in stabilizing the $\mathrm{T}$ helper cell type 1 and 2 phenotype. J Immunol 1997; 158: 2648 - 2653.

16. Tinkle SS, Schwitters PW, Newman LS. Cytokine production by bronchoalveolar lavage cells in chronic beryllium disease. Environ Health Perspect 1996; 104: 969-971.

17. Bergeron A, Bonay $\mathrm{M}$, Kambouchner $\mathrm{M}$, et al. Cytokine patterns in tuberculous and sarcoid granulomas. J Immunol 1997; 159: $3034-3043$.

18. Hirano T. Interleukin-6. In: Thomson AW, ed. The Cytokine Handbook. San Diego: Academic Press, 1998; pp. 197-228.

19. Mroz MM, Kreiss K, Lezotte DC, Campbell PA, Newman LS. Re-examination of the blood lymphocyte transformation test in the diagnosis of chronic beryllium disease. J Allergy Clin Immunol 1991; 88: $54-60$.

20. Bobka CA, Stewart LA, Engelken GJ, Golitz LE,
Newman LS. Comparison of in vivo and in vitro measures of beryllium sensitization. J Occup Environ Med 1997; 39: 540 - 547.

21. Curtis GH. Cutaneous hypersensitivity due to beryllium: A study of thirteen cases. AMA Arch Dermatol Syph 1951; 64: 470-482.

22. Röcken M, Urban J, Shevach EM. Antigen-specific activation, tolerization, and reactivation of the interleukin 4 pathway in vivo. J Exp Med 1994; 179: $1885-1893$.

23. Hogaboam CN, Vallance BA, Kumar A, et al. Therapeutic effects of interleukin-4 gene transfer in experimental inflammatory bowel disease. J Clin Invest 1997; 100: 2766-2776.

24. Joosten LAB, Lubberts E, Durez P, et al. Role of interleukin-4 and interleukin-10 in murine collageninduced arthritis: Protective effect of interleukin-4 and interleukin-10 treatment on cartilage destruction. Arthritis Rheum 1997; 40: 249-260.

25. van Roon JAG, van Roy JLAM, Gmelig-Meyling FHJ, Lafeber FPJG, Bijlsma JWJ. Prevention and reversal of cartilage degradation in rheumatoid arthritis by interleukin-10 and interleukin-4. Arthritis Rheum 1996; 39: 829-835.

26. Gautam S, Tebo JM, Hamilton TA. IL-4 suppresses cytokine gene expression induced by IFN- $\gamma$ and/or IL-2 in murine peritoneal macrophages. $J$ Immunol 1992; 148: $1725-1730$.

27. D'Andrea A, Ma X, Aste-Amezaga M, Paganin C, Trinchieri G. Stimulatory and inhibitory effects of interleukin (IL)-4 and IL-13 on the production of cytokines by human peripheral blood mononuclear cells: priming for IL-12 and tumor necrosis factor $\alpha$ production. J Exp Med 1995; 181: 537-546.

28. Tanaka T, Hu-Li J, Seder RA, Fazekas de St. Groth B, Paul WE. Interleukin 4 suppresses interleukin 2 and interferon $\gamma$ production by naive $\mathrm{T}$ cells stimulated by accessory cell-dependent receptor engagement. Proc Natl Acad Sci USA 1993; 90: 5914-5918.

29. Hsieh CS, Heimberger AB, Gold JS, O'Garra A, Murphy KM. Differential regulation of $\mathrm{T}$ helper phenotype development by interleukins 4 and 10 in an $\alpha \beta$ T-cell-receptor transgenic system. Proc Natl Acad Sci USA 1992; 89: 6065-6069.

30. Murphy E, Shibuya K, Hosken N, et al. Reversibility of $\mathrm{T}$ helper 1 and 2 populations is lost after long-term stimulation. J Exp Med 1996; 183: 901 -913.

31. Seder RA, Paul WE, Davis MM, Fazekas de St. Groth B. The presence of interleukin 4 during in vitro priming determines the lymphokine-producing potential of $\mathrm{CD}^{+}{ }^{+} \mathrm{T}$ cells from $\mathrm{T}$ cell receptor transgenic mice. J Exp Med 1992; 176: 1091 - 1098.

32. Hamada H, Sawyer RT, Kittle LA, Newman LS. Beryllium stimulation does not activate transcription factors in a mouse hybrid macrophage cell line. Toxicology 2000; 143: 249-261.

33. Sambrook J, Fritsch EF, Maniatis T. Molecular cloning: a laboratory manual. Plainview, New York: Cold Spring Harbor Laboratory Press, 1989.

34. Hosken NA, Shibuya K, Heath AW, Murphy KM, $\mathrm{O}^{\prime}$ Garra A. The effect of antigen dose on $\mathrm{CD} 4^{+} \mathrm{T}$ helper cell phenotype development in a $\mathrm{T}$ cell receptor$\alpha \beta$-transgenic model. J Exp Med 1995; 182: 1579 1584.

35. Carballido JM, Carballido-Peffig N, Terres G, Heusser CH, Blaser K. Bee venom phospholipase A2-specific $\mathrm{T}$ cell clones from human allergic and 
non-allergic individuals: cytokine patterns change in response to the antigen concentration. Eur J Immunol 1992; 22: $1357-1363$.

36. Hart PH, Bonder CS, Balogh J, Dickensheets HL, Donnelly RP, Finlay-Jones JJ. Differential responses of human monocytes and macrophages to IL-4 and IL13. J Leukoc Biol 1999; 66: 575-578.

37. Gollob KJ, Dutra WO, Coffman RL. Early message expression of interleukin- 4 and interferon- $\gamma$, but not of interleukin-2 and interleukin-10, reflects later polarization of primary $\mathrm{CD}^{+}$cell cultures. Eur J Immunol 1996; 26: $1565-1570$.
38. Milburn HJ, Poulter LW, Dilmec A, Cochrane GM, Kemeny DM. Corticosteroids restore the balance between locally produced Th1 and Th2 cytokines and immunoglobulin isotypes to normal in sarcoid lung. Clin Exp Immunol 1997; 108: 105-113.

39. Banchereau J, Steinman RM. Dendritic cells and the control of immunity. Nature 1998; 392: 245-252.

40. Secrist H, DeKruyff RH, Umetsu DT. Interleukin 4 production by $\mathrm{CD}^{+}{ }^{+} \mathrm{T}$ cells from allergic individuals is modulated by antigen concentration and antigen-presenting cell type. $J$ Exp Med 1995; 181: $1081-1089$. 